\title{
UTILIZATION OF THE EDUCATION MANAGEMENT INFORMATION SYSTEM (EMIS) AS A DECISION MAKING MEANS IN THE INSTITUTIONAL SECTION OF THE REGIONAL OFFICE OF THE MINISTRY OF RELIGION, YOGYAKARTA SPECIAL REGION
}

\author{
Luhur Arroyan \& Nurlaila Subekti \\ State Islamic University Sunan Kalijaga Yogyakarta,Bachelorwiyata University Tamansiswa \\ 19204090008@uin-suka.ac.id, Lalanew92@gmail.com
}

\begin{abstract}
This study was conducted to determine the utilization of the education management information system (EMIS) as a means of decision making in the institutional section at the Regional Office of the Ministry of Religion, Yogyakarta Special Region. This research is a qualitative research using data collection techniques in the form of interviews, observations, and documentation. Technical analysis of data using data reduction, data presentation, and drawing conclusions. This research focuses on objective results with research subjects who really know, experience, and understand in this case the head of the madrasa education sector, along with the operator and the head of the SIM institutional section. The results of the study show that the basis for decision making can be completed because it has been accumulated by regulations and adopted the opinion of top managers. If the alternative answers are not satisfactory, the analysis will continue with deliberation with stakeholders and elements of the madrasa.Decision-making and Utilization of EMIS data during the study showed that EMIS plays a role in the distribution of the budget contained in the PIP program (smart Indonesia program), Madrasah BOS, National Examination student data, transfer and appointment of principals, equitable distribution of teachers and madrasa infrastructure, and the contribution of data The EMIS is utilized by the People's and Community Welfare Bureau, and the Provincial Government Legal Bureau. In addition, EMIS also plays a role in providing infrastructure assistance. EMIS development needs to be improved with new innovations. Data updates must be done frequently, always input as long as there are dynamics of data changes so that they are up to date. Reports on development, development, performance improvement should be based on EMIS data. The dynamics in society continue to exist at all times, for example there are students who move, teachers who transfer, teachers who are appointed as acting. Then EMIS must be updated every day.
\end{abstract}

Keywords: Management, Information System, Decision 


\section{INTRODUCTION}

The development of technology, information, and communication has changed the perspective and practice of management in all fields including education. ${ }^{1}$ Technology has undergone a development revolution, which was originally a traditional system into a modern information technology-based system to achieve more and more performance optimization goals. The management information system is a key part of the institution because the data information presented is of work effectiveness and efficiency. In the current information era, it is very necessary to have a management information system where the information has been processed according to good standards and can be accounted for.

One of the uses of information technology is as a means of making decisions in educational institutions. The decisions taken can vary based on the types of leadership. Leaders need accurate information data for the most strategic decision making, if the information is lacking or incorrect, it can be ascertained that there will be significant problems. Therefore, educational institutions must have a data collection system that is accurate, good, easy, effective, and efficient. Then the existing information technology system must be utilized optimally with the intention, the more expert an information technology operator the result is the quality of the data or information produced. ${ }^{2}$ The goal is to get quality data, because technology creates quality data in an effective and efficient way. In contrast to the past, obtaining good quality data takes a long time, costs a lot of money, and involves a lot of people. It can be compared that the utilization of technology is very necessary based on the evidence and statements above, so that institutions or organizations that use information technology can meet their needs or even exceed the desired expectations.

The Regional Office of the Ministry of Religion of the Special Region of Yogyakarta is a vertical agency centered on the Ministry of Religion of the Republic of Indonesia. Has a madrasa data collection system that contains madrasa data in the form of profiles,

${ }^{1}$ Fuadi Aziz, "Policy Making Based on Education Management Information System (EMIS) at the Mapenda of the Ministry of Religion of Gunungkidul Regency", Journal of Islamic Education, 3 (1) 2014: 135

${ }^{2}$ The results of observations with the madrasah education management information system staff KANWIL, Bp. Shodiq Auliya. S. Kom. 
students, curriculum, teachers, and so on. The management information system, known as the Education Management Information system (EMIS), is a data server that contains management information that organizes all data from education, especially for madrasas throughout the Special Region of Yogyakarta. ${ }^{3}$ Therefore, the importance of the EMIS information system needs to be increased, especially the input, process, and output, for example by understanding, counseling, coaching, monitoring, and controlling to operators and parties related to EMIS management so that the information obtained is of high quality. This quality is embraced by leaders as making a good policy. Good policy making can be in the form of policy formulation, budgeting, decision making, planning for education, and developing religious education. ${ }^{4}$

EMIS (Education Management Information System)is an online application that functions to document madrasa information needed in policy making, while the content of the EMIS is madrasa information data which is always updated during the semester. The information contained in the EMIS is not always static. Based on the statement that information is dynamic, policy making must also be dynamic following the direction of existing information in order to create policy results as expected. From the explanation above, the researcher analyzed the utilization of EMIS as a Decision Making Tool in the Institutional and SIM Section of the Regional Office of the Ministry of Religion of DIY which focused on the main description of the management of EMIS information data by the operator of the Regional Office of the Ministry of Religion of DIY, the effectiveness of EMIS data as a basis for decision making, and utilization EMIS data as the basis for decision making.

\section{RESEARCH METHODS}

This research was conducted using a descriptive qualitative method, namely research that produces data in the form of transcripts of the respondent's answers to accurately describe a situation, individual characteristics or symptoms that occur in certain groups.

\footnotetext{
${ }^{3}$ Ministry of Religion of the Republic of Indonesia, Taking Work Relations of the Directorate General (Jakarta: Ministry of Religion, 2003), p.17.

${ }_{4}$ Dodi Irawan Syarif and Rosidin, Educational Data and Information Management System within the Directorate General of Islamic Institutions, Jakarta: Ministry of Religion of the Republic of Indonesia, Directorate General of Islamic Institutions, 2003), pp.26-27.
} 
Furthermore, the sampling technique used in this study is purposive sampling, which is a method of sampling that is carried out intentionally in accordance with the sample criteria. The sample criteria referred to in this study are people who understand, know, and experience the problems being studied. The samples taken did not emphasize the number or representation, but prioritized the quality of information, credibility and richness of information owned by the informants or participants. ${ }^{5}$ In the process of processing qualitative data, valid methods are needed in analyzing data in order to obtain complete, precise, and correct research results. The analysis used in this research is the interactive analysis of Miles and Huberman ${ }^{6}$ namely by reducing data, presenting data, and drawing conclusions or verifying data which is done to answer the formulation of the research problem.

\section{RESULTS AND DISCUSSION}

Management of Education Management Information System (EMIS) Information Data in the Institutional and SIM Section of the Regional Office of the Ministry of Religion DIY

The EMIS application is software developed to collect madrasa data and as a database for madrasah educational institutions in Indonesia. EMIS is directly managed by the directorate of madrasah institutional section of madrasah information systems and Islamic education, the data contained includes student data, institutional data including institutional identity, curriculum and infrastructure, and CAR data (educators and education personnel). The central EMIS serves as a place to collect existing data in Indonesia, while the role of the provincial and district level ministries is as accomplices in charge of counseling, supervision, and observation.

The simplest means of collecting EMIS data are computers, internet networks, and mastering the EMIS program. The flow of EMIS data collection begins with information addressed to KANWIL and continues with resource visits from regional center EMIS operators to provide counseling to all operators in madrasas,

${ }^{5}$ Conny R. Setiawan, Qualitative Research Methods: Types, Characteristics and Advantages (Jakarta: Grasindo, 2010), p. 115.

${ }^{6}$ Sugiyono, "Research Methods.... p.337. 
both from Raudatul Athfal, Madrasah Ibtidaiyah, Madrasah Tsanawiyah, and, Madrasah Aliyah. The initial socialization was carried out for one month with the hope that it would be effective so that data collection for the next 11 months was ready for use.

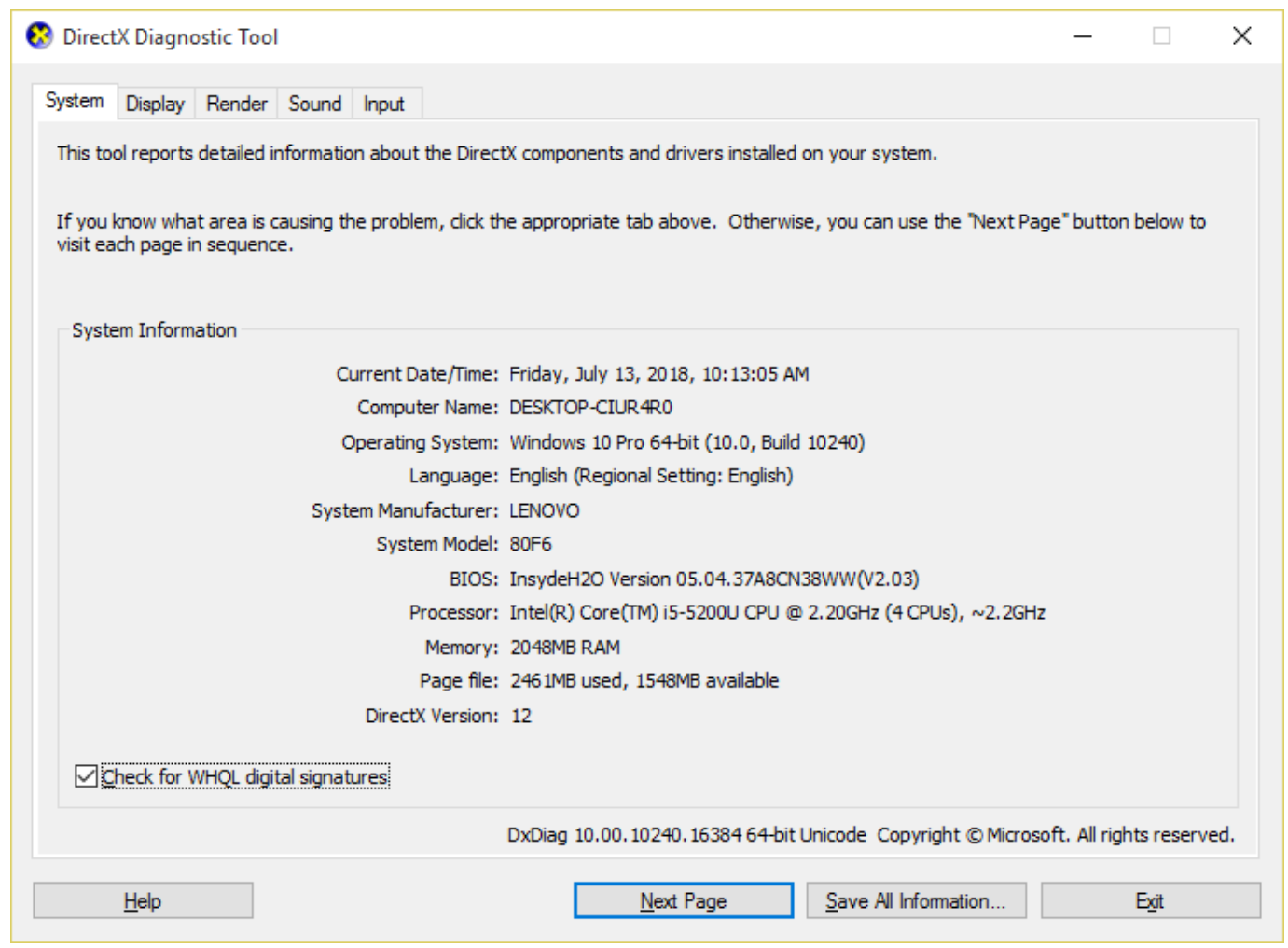

Picture 1 EMIS computer specifications

Source: Documentation of Institutional Section Staff and SIM Mr. Shodik

EMIS infrastructure standards are at least those mentioned in the previous explanation. This is important so that its provision and use is appropriate. The purpose of managing educational information system infrastructure in general is to provide professional facilities and services in the field of madrasah data services in order to realize the decision-making process. ${ }^{7}$

7 Prastyawan, "Management of Educational Facilities and Infrastructure", Journal of Islamic Studies, 6 (1), 2016: 4. 


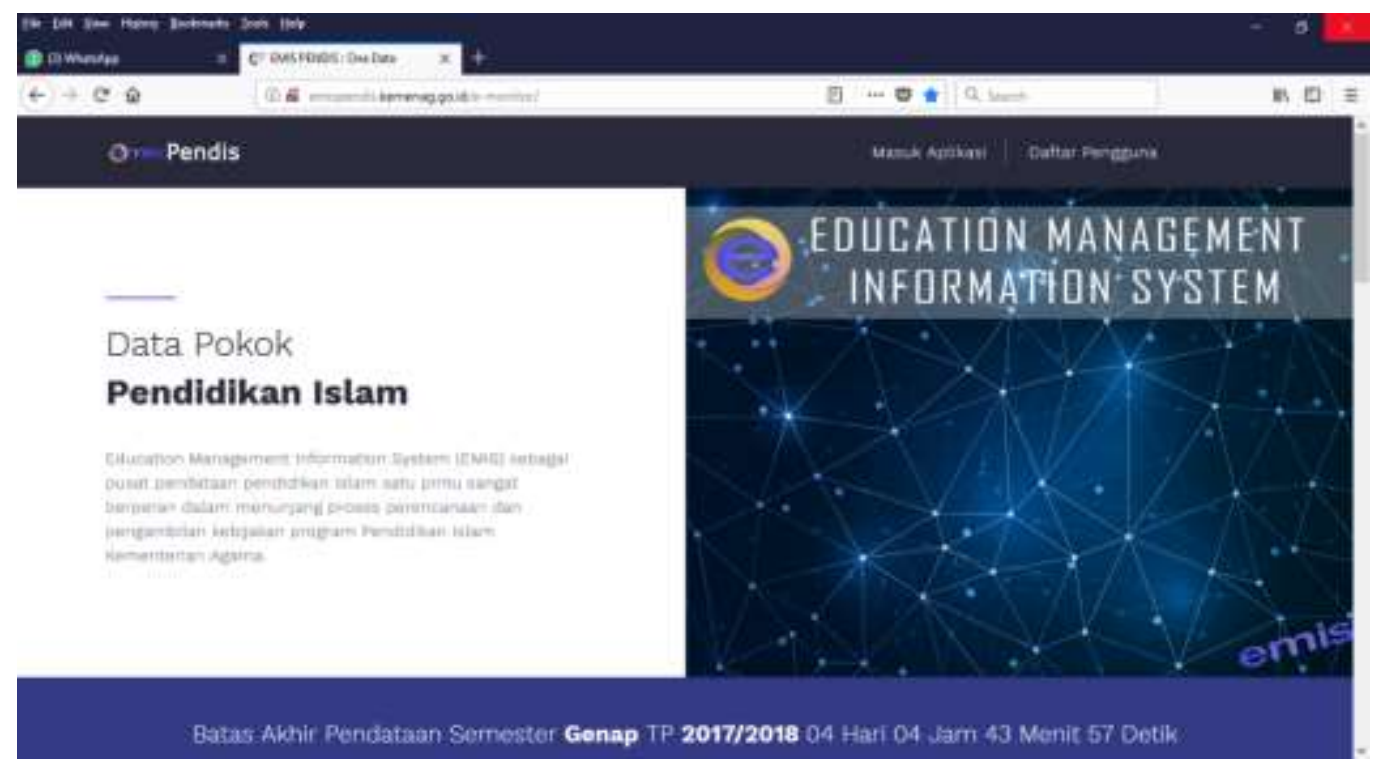

Picture 2 EMIS Application Initial View

Source: Documentation of Institutional Section Staff and SIM Mr. Shodik

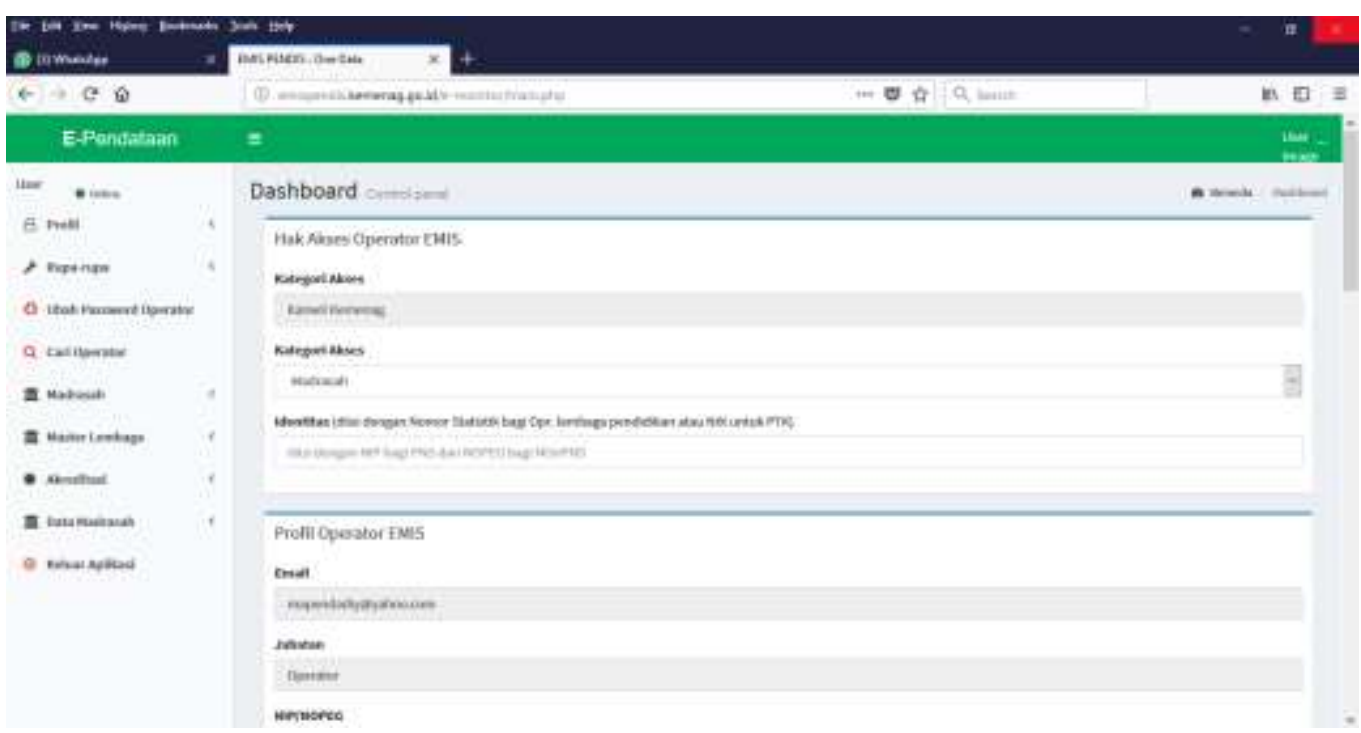

Picture 3 EMIS In-App Display

Source: Documentation of Institutional Section Staff and SIM Mr. Shodik 
The management of the national education system as stated in the law is the responsibility of the Minister. ${ }^{8}$ So, to implement the law, the Institutional Section of Dikmat anticipates data security by doing a double system, which means running an online system in conjunction with a manual system (exel form). Some literature describes a dual system or backup is useful for two main purposes. First, to restore data that has been damaged by natural disasters (eg floods, earthquakes). Second, to restore files after experiencing error deleting or data corruption. ${ }^{9}$ Presenting data into EMIS information depends on policy needs. EMIS publishes information data that can later be used as a basis for policy and mapping, besides that the data can be used for several stakeholders. No less important is to provide good and accountable information to the general public as well as reality. It is explained in the regulations that agencies that require EMIS information data must submit an application letter to the Regional Office followed by the head of DIKMAT and the SIM institutional section. ${ }^{10}$

\section{Decision-making}

1. Decision Making Basis

The Ministry of Religion has the role of implementing laws or regulations. Decision making through a decision-making process related to situations, conditions, considerations, thinking, interpreting, choosing, and predicting something. ${ }^{11}$ The problems that occur in the scope of education and madrasas can be resolved because they have been accumulated by regulations, so the basis for problem solving is regulation. ${ }^{12}$ The core issue here is whether the problems can be solved by regulation or not.

Decision making is based on discussion or deliberation analysis with several stakeholders and elements of madrasas for all levels. The level of the madrasa

${ }^{8}$ Anonymous, RI Law, No. 20 of 2003, National Education System, Article 50, Paragraph 1.

${ }^{9}$ Edi Wijaya, et al, "Designing a Data Backup Automation System Using a File Transfer Protocol Based on a LAN Network (Case Study on STMIK TIME Medan)", TIMES Journal, 4 (1), 2015: 26-30.

${ }^{10}$ Research Interview with Bp. Mukotib M.Ag. The Institutional Section for Madrasah Education, the Regional Office of the Ministry of Religion, Yogyakarta,

${ }^{11}$ Imam Machali and Ara Hidayat, The Handbook Of Education Management Theory and Practice of School Management in Indonesia, (Jakarta: Parenadamedia Groub, 2016) p. 113

${ }^{12}$ Research interview with Bp. M. Nadif S.Ag, MSI Head of Madrasah Education Regional Office of the Ministry of Religion Yogyakarta 
education section of the district and city schools and can listen to the aspirations of the community. In conclusion, the problem is solved on the basis of normative decision making, namely by regulation and discussion of deliberation analysis.

The basis of decision making above has similarities with some of Evy's literature which explains the basis for making decisions that can adopt the opinion of top managers. ${ }^{13}$ Here there are similarities between regulations and top managers where the rules are the normative basis and become the basic benchmark for decision making by all parties. If the alternative answers are not satisfactory, the analysis will continue with deliberation with stakeholders and elements of the madrasa.

2. Internal and External Factors of Decision Making

In order to predict future information data needs, it is necessary to know the factors that influence the development of education. Both external factors of education and internal factors of education. The influencing factors can be of different kinds, in this case the informants emphasize the types of internal and external factors as the basis for decision making.

Internal factors that need to be considered in making decisions in the scope of DIY, the resource person explained the main problems experienced by the education system in DIY during the 4 years he served or previous officials were the availability of budget and human resources (human resources) who were less skilled in technology based on survey of BAN-SM (National Accreditation Board for Schools/Madrasah). Availability of the budget, so we don't face all the problems, we don't face all the strategic issues, we don't immediately provide solutions in a moment, of course there will be a priority scale, based on the availability of the budget that we prepare starting from the madrasa, Regency City and, Territory. HR, how big is the ability of $\mathrm{HR},{ }^{14}$

Based on the explanation above, the core of all existing problems will be resolved by calculating the priority scale first. This opinion is in harmony with

\footnotetext{
${ }^{13}$ Evy Ramadina, "Management ..., :5.

${ }^{14}$ Research interview with Bp. M. Nadif S.Ag, MSI Head of Madrasah Education Regional Office of the Ministry of Religion Yogyakarta.
} 
Sholihudin's literature which explains that internal factors are the internal state of the organization, including: financial, quality of human resources, completeness of infrastructure, organizational structure, availability of information needed by managers, and so on. ${ }^{15}$

External factors are factors that influence a decision from outside. Those who are considered important and have a great influence on the madrasa education system are the Education Office of Dikpora, local government, and the community. As in the theory of external factors which constitute a decision, among others; economic, social, political, legal, cultural, and so on. ${ }^{16}$ The conclusion is that external factors in decision making come from outside the agency that affect the shape of the results of the decision here mentioned the Education Office of Dikpora, local government, and the community.

\section{Other Factors Supporting Decision Making from EMIS}

In addition to EMIS data that supports decision making, namely the results of routine monitoring and evaluation. This is all held in the context of synchronizing EMIS data with conditions in the field. The synchronization of EMIS data with the results of field evaluations was carried out in anticipation of the validity of the existing data by mentors from regional offices and the Ministry of Religion of the City District. ${ }^{17}$

An evaluation system mechanism needs to be implemented so that what is expected from the decision can be realized. ${ }^{18}$ The above opinion means that evaluation is very useful for collecting, assessing and making decisions on the implementation and effectiveness of a program. Evaluation is a process of providing information that can be used as a consideration for determining prices and services (program implementation). ${ }^{19}$ In conclusion, other factors that support decisions that

15 Solihuddin Arif, Imam Machali, "PROCEEDING The 1st Annual Conference on Islamic Education Management (ACIEM)", Islamic Education Management for Millennial Generation; Quality and Competitiveness $2018: 719$.

${ }^{16}$ Solihuddin Arif, Imam Machali, "PROCEEDING The..., : 719.

${ }^{17}$ Research interview with Bp. M. Nadif S.Ag, MSI Head of Madrasah Education at the Yogyakarta Ministry of Religion Regional Office, Wednesday.

${ }^{18} \mathrm{Imam}$ Machali and Ara Hidayat, The Handbook Of ..., p. 114.

19 Lukas Luiuran, "Evaluation of the Implementation of KTSP and 2013 Curriculum in Vocational High Schools in Belu Regency, East Nusa Tenggara", Journal of Educational Research and Evaluation, 22 (1), 2018: 3. 
are close to perfection are field monitoring and evaluation, to make decisions, it should require many factors that build up the more factors, the more confident the decision can be a solution.

\section{EMIS Data-Based Decision Making}

Decision making is the most important function of actuating, the core of the organization is leadership and the core of leadership is decision making, the right decision is a decision that is weighty and can be accepted by subordinates. ${ }^{20}$ The madrasa education sector and the SIM institutional section are responsible for handling decisionmaking, acceptance, and finalization of decisions at the DI Yogyakarta regional level. The steps behind the decision-making process, namely problem identification, problem flow, and alternative problem solvers. The Dikmat sector and the SIM institutional section will hold an annual working meeting when making decisions to discuss strategic issues. The strategic issues are problems faced by the community that are directly related to education. For this reason, it must invite elements that will formulate the answer, elements outside the organization who have influence in a decision-making process in a social organization. ${ }^{21}$ The elements are madrasah, community, City Regency stakeholders and partner agency stakeholders. The community has the right to participate in the planning, implementation, monitoring and evaluation of educational programs. ${ }^{22}$ The gathering of all these elements can then identify developing problems and formulate programs, namely: ${ }^{23}$

${ }^{20}$ Imam Machali and Ara Hidayat, The Handbook Of..., p. 112.

${ }^{21}$ Hery Basuki, "Decision Making Process in Social Organizations", Translitera Journal, 1 (3) $2015: 57$.

22 Anonymous, Law, No.20 of 2003, Concerning the National Education System, Article 8.

${ }^{23}$ Research interview with Bp. M. Nadif S.Ag, MSI, Head of Madrasah Education at the Regional Office of the Ministry of Religion, Yogyakarta. 


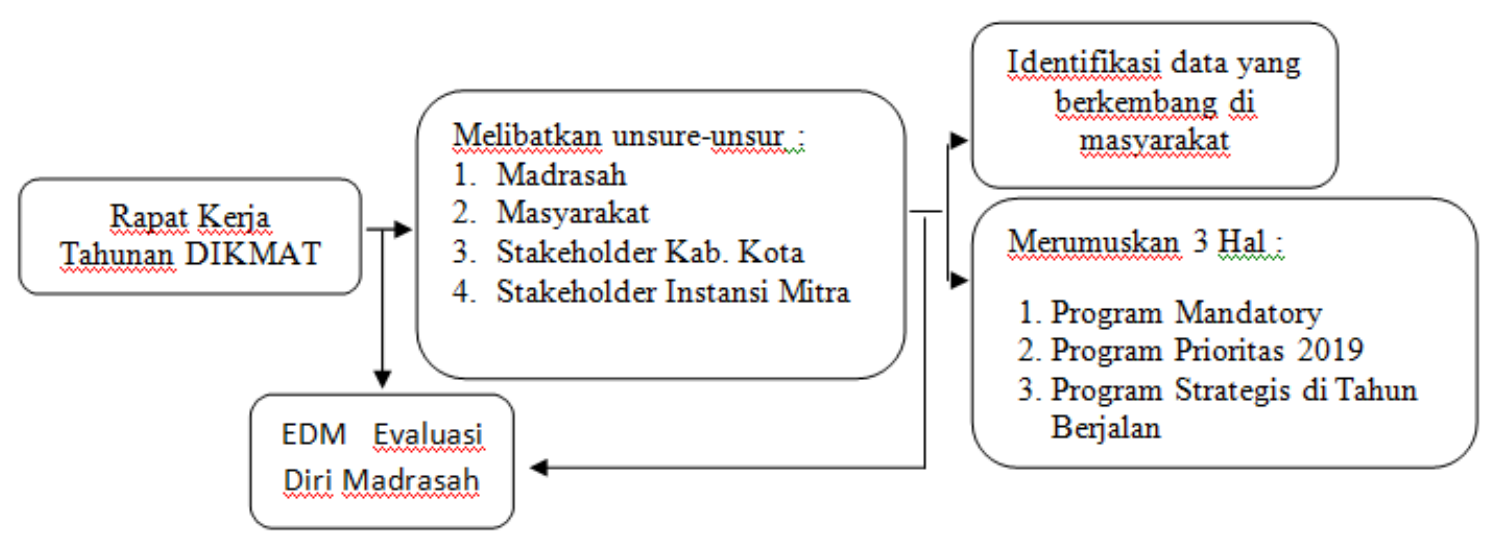

Picture 4 Decision Making Flow

The program formulated above is then continued with problem identification by applying it to the program. To find the source of the problem, an investigation was carried out with the EDM (madrasah self-evaluation) instrument which was filled in by each madrasa. The main actors filling the EDM instrument include the head of the madrasa, teachers, students and committees here, it is conveyed that none of the parties who fill out the instrument is not based on honesty, it must be what it is so that it will be seen by the supervisor if the madrasah this is having problems. In fact, when we talk about problem identification, besides coming from national strategic issues, it also comes from the madrasa itself when analyzing the actual conditions in the madrasa. ${ }^{24}$

From the explanation about the identification of decision making in line with the literature that was expressed by Evy Ramadina, the decision making process must examine the identification of problems, determine the criteria for the problem, and seek alternative solutions to problems based on the level of importance. The subject matter must have a priority scale which should be prioritized or prioritized and which should be light. ${ }^{25}$ As well as emphasized by Moekijat's theory, to filter the alternatives that have been found, two kinds of tasks are needed, namely identifying or categorizing alternative solutions and investigating solutions in a certain category. ${ }^{26}$

\footnotetext{
${ }^{24}$ Research interview with Bp. M. Nadif S.Ag, MSI Head of Madrasah Education Regional Office of the Ministry of Religion Yogyakarta.

${ }^{25}$ Evy Ramadina, "Management ..., : 1.

${ }^{26} \mathrm{Ibn}$ Syamsi, Taking..., p.
} 
Taking into account the management of EMIS, EMIS is actually an official data collection facilitated by the Ministry of Religion for madrasas. The person in charge and manager of EMIS is BEN ITE (national education, information technology) Center at the Ministry of Religion of the Republic of Indonesia, directorate of Curriculum, Facilities, Institutions and Madrasah Students. According to its function, actually want to take a data-based policy which means EMIS data. Not just making a decision on an issue or accommodating a mere desire, but really based on data. ${ }^{27}$ What about the management of EMIS data for the institutional section of DIKMAT, due to the influence of the domain in the central EMIS, when can EMIS be entered, when can it be updated, it has been scheduled for at least a year, twice odd and even semesters. After the update process has been completed, each madrasa must enter or update data. So the data obtained from EMIS are valid data because they are based on the new road, not based on a button up, not an entry supervisor, but really in accordance with the conditions of the madrasa. The data that has been collected then becomes a reference for determining policies. When the relevant officials here, the institutional section flows to the Regional Office and will take data-based policies, this has implications for the provision of assistance, infrastructure and others. ${ }^{28}$

EMIS data management looks like the above can be used to channel aid or budget in the right way, according to known information data. This opinion is confirmed by the existence of literature from Dewi explaining the use of electronic information systems in the form of data in an institution that will help service users to obtain important information concerning themselves, meaning to make the most appropriate decisions. ${ }^{29}$ And Muthohir's opinion about the use of information data as a way to minimize errors, speed up checking of goods and facilitate financial reporting solely for the purpose of facilitating and accelerating services to consumers. ${ }^{30}$

\footnotetext{
${ }^{27}$ Research interview with Bp. M. Nadif S.Ag, MSI, Head of Madrasah Education at the Regional Office of the Ministry of Religion, Yogyakarta.

${ }^{28}$ Research interview with Bp. M. Nadif S.Ag, MSI, Head of Madrasah Education at the Regional Office of the Ministry of Religion, Yogyakarta.

${ }^{29}$ Dewi Kartikasari, "The Information System for Hajj and Umrah Services at PT. Andromeda Atria Wisata Surabaya”, (2009). Thing. 67

${ }^{30}$ Musrifah and Muthohir, Information Systems ... , p.14.
} 
In conclusion, the use of EMIS data during the study shows that EMIS plays a role in the distribution of the budget contained in the PIP program (the Smart Indonesia program), Madrasah BOS, National Examination student data, transfers and appointments of principals, equal distribution of teachers and madrasa infrastructure, and the contribution of EMIS data that utilized by the Bureau of People's and Community Welfare, and the Legal Bureau of the Provincial Government. Apart from him, EMIS also plays a role in providing infrastructure assistance.

\section{CONCLUSION}

The results of the study show that the basis for decision making can be completed because it has been accumulated by regulations and adopted the opinion of top managers. If the alternative answers are not satisfactory, the analysis will continue with deliberation with stakeholders and elements of the madrasa.Decision-making and Utilization of EMIS data during the study showed that EMIS plays a role in the distribution of the budget contained in the PIP program (smart Indonesia program), Madrasah BOS, National Examination student data, transfer and appointment of principals, equitable distribution of teachers and madrasa infrastructure, and the contribution of data The EMIS is utilized by the People's and Community Welfare Bureau, and the Provincial Government Legal Bureau. In addition, EMIS also plays a role in providing infrastructure assistance. EMIS development needs to be improved with new innovations. Data updates must be done frequently, always input as long as there are dynamics of data changes so that they are up to date. Reports on development, development, performance improvement should be based on EMIS data. The dynamics in society continue to exist at all times, for example there are students who move, teachers who transfer, teachers who are appointed as acting. Then EMIS must be updated every day. 


\section{BIBILOGRAPHY}

Anonim, Undang-undang, No. 20 Tahun 2003, tentang Sistem Pendidikan Nasional.

Arif, Sholihuddin. (2016). Pemanfaatan Education Management Information System (EMIS) Sebagai Sarana Pengambilan Keputusan di Seksi PAI Kementerian Agama Kabupaten Gunungkidul, Skripsi, Fakultas Ilmu Tarbiyah dan Keguruan UIN Sunan Kalijaga Yogyakarta.

Arif Solihuddin, dan Imam Machali, (2018) "PROCEEDING The 1 Annual Conference on Islamic Education Management (ACIEM)", Islamic Education Management for Millenial Generation;Quality and Competitiveness.

Hutahaean, Jeperson, (2015). Konsep Sistem Informasi, Yogyakarta: Deepublish.

Jogiyanto. (2011). Sistem Informasi Manajemen, Yogyakarta: Universitas Terbuka.

Machali Imam dan Ara Hidayat. (2016). The Handbook Of Education Management Teori dan Praktik. Pengelolaan Sekolah Di Indonesia. Jakarta : Parenadamedia Group.

O’brian, James A. and George M. Marakas. (2014). Sistem Informasi Manajemen. Jakarta: McGraw-Hill Education.

Prastyawan. (2016). "Manajemen Sarana dan Prasarana Pendidikan", Jurnal Studi Keislaman, 6 (1).

Rachamd Syafa'at. (2006). Advokasi dan Piliban penyelesaian Sengketa, Latar Belakang, Konsep dan Implementaasinya. Malang: Yayasan Pembangunan Nasional (YPN).

Ramadina, Evy. (2017). "Pengelolaan Education Management Information System (EMIS) dalam Pengambilan Keputusan”, Jurnal Sistem Informasi Indonesia (JSII).

Sugiyono. (2015). Metode Penelitian Pendidikan (Pendekatan Kuantitatif, Kualitatif, dan R\&D), Bandung: Alfabet.

Sunyoto, Danang. (2014). Sistem Informasi Manajemen (Perspektif Organisasi), Yogyakarta: CAPS.

Wawancara penelitian dengan Bp. M. Nadif S.Ag, M.S.I Kepala bidang pendidikan madrasah kantor wilayah kementerian agama Yogyakarta.

Wawancara Penelitian dengan Bp. Mukotib M.Ag. Seksi Kelembagaan bidang pendidikan madrasah kantor wilayah kementerian agama Yogyakarta. 